\title{
APOA4 wt Allele
}

National Cancer Institute

\section{Source}

National Cancer Institute. APOA4 wt Allele. NCI Thesaurus. Code C116604.

Human APOA4 wild-type allele is located in the vicinity of $11 \mathrm{q} 23$ and is approximately $3 \mathrm{~kb}$ in length. This allele, which encodes apolipoprotein A-IV protein, plays a role in the modulation of chylomicron and very low density lipoprotein transport. 